\title{
STUDI FENOMENOLOGIS AKULTURASI PSIKOLOGIS PADA MAHASISWA THAILAND DI UNIVERSITAS ISLAM SULTAN AGUNG SEMARANG
}

\author{
Malisa Falasifah, Siti Maya Cahyanti, dan Amara Difa Nurl Hasanah J.M \\ Fakultas Psikologi Universitas Islam Sultan Agung Semarang \\ Email: falasifahmalisa@gmail.com
}

\begin{abstract}
Abstrak
Penelitian ini bertujuan untuk mengetahui akulturasi psikologis pada mahasiswa Thailand di Universitas Islam Sultan Agung (Unissula) Semarang. Metode yang digunakan di dalam penelitian ini adalah pendekatan kualitatif dengan metode fenomenologis. Sebanyak empat partisipan berhasil direkrut dengan teknik purposive dan snowball sampling. Data dikumpulkan melalui observasi dan wawancara semi-terstruktur dan dianalisis menggunakan interpretative phenomenological analysis (IPA). Hasil penelitian ini mengungkapkan bahwa kemiripan budaya asal dan budaya baru, usia saat bermigrasi, latar belakang pendidikaan, kepribadian individu dan pengetahuan individu merupakan faktor penting yang mempengaruhi akulturasi psikologis pada mahasiswa Thailand dii Unissula. Walaupun begitu, partisipan masih mengalami hambatan akulturasi psikologis yaitu hambatan komunikasi yang disebabkan oleh adanya perbedaan bahasa. Hambatan ini menimbulkan dampak psikologis yaitu kejutan budaya (culture shock) sehingga partisipan melakukan strategi akulturasi psikologis. Strategi yang digunakan oleh partisipan di dalam penelitian ini adalah integrasi.
\end{abstract}

Kata kunci: Akulturasi psikologis, mahasiswa Thailand

\section{PHENOMENOLOGICAL STUDY OF PSYCHOLOGICAL ACCULTURATION OF THAILAND STUDENTS IN SULTAN AGUNG SEMARANG ISLAMIC UNIVERSITY}

\begin{abstract}
The purpose of this study is to explore the psychological acculturation among Thailand students of Sultan Agung Islamic University Semarang. Method that being used in this study is qualitative approach with phenomenological method. A total of four participants successfully being recruited with purposive technique and snowball sampling. Data collected using observation and semi-structured interview then analyzed with interpretative phenomenological analysis (IPA). The result of this study shows that the similarity within origin culture and new culture, age at migration, educational background, individual personality and individual knowledge are important factors that influenced psychological acculturation in Thai students at Unissula. Despite of these factors, participants still experience communication problem that being caused by difference in language. This obstacle had a psychological effect, which is culture shock until they carried out a psychological acculturation strategy. The strategy used by the participants in this study is integration.
\end{abstract}

Keywords: psychological acculturation, Thailand students

\section{Pendahuluan}

Sebagai bagian dari masyarakat global, Indonesia turut andil dalam meningkatkan kualitas pendidikan dengan membuka peluang sebesar-sebesarnya bagi mahasiswa asing yang ingin melanjutkan pendidikan di perguruan tinggi di Indonesia. Salah satu kegiatan untuk mencapai tujuan tersebut adalah dengan melakukan kerjasama dalam bidang akademik maupun non akademik dengan pihak lain dari dalam dan luar negeri seperti perguruan tinggi lain atau suatu perusahaan. Hal ini sesuai 
Malisa Falasifah, Siti Maya Cahyanti, dan Amara Difa Nurl Hasanah J.M.

dengan Peraturan Menteri Pendidikan dan Kebudayaan Republik Indonesia nomor 14 tahun 2014 pasal 4. Kerjasama ini dapat mempererat hubungan antar negara dan kepercayaan masyarakat internasional serta meningkatkan kualitas pendidikan melalui benchmarking dengan perguruan tinggi luar negeri.

Dalam rangka mengemban visi global untuk meningkatkan kualitas pendidikan, Universitas Islam Sultan Agung (Unissula) Semarang telah melakukan kerjasama dalam bentuk beasiswa internasional dengan Muslim Education Development Association of Thailand (MEDAT). Unissula dan MEDAT sudah menjalin kerjasama sejak tahun 2015 hingga sekarang serta telah menerima lebih dari dua puluh mahasiswa baru dari Thailand. Berdasarkan informasi dari Office of International Affair (OIA) Unissula, mahasiswa baru dari Thailand mendapatkan pelatihan intensif dari Pusat Pengembangan Bahasa Internasional (CILAD) Unissula agar mereka dapat segera berbaur dan lebih mudah beradaptasi dengan lingkungan sekitar maupun untuk sisi akademik. Selain itu, mahasiswa baru dari Thailand juga ditempatkan di Pesantren Mahasiswa Sultan Agung (Pesanmasa) yang merupakan asrama mahasiswa yang terletak di dalam lingkungan kampus Unissula. Tujuannya adalah agar mahasiswa bisa lebih mudah adaptasi terhadap lingkungan sekitar.

Berdasarkan wawancara yang telah dilakukan dengan beberapa musyrif (pengurus) asrama, sebagian besar dari mahasiswa Thailand mengalami masalah dalam penyesuaian diri. Mereka lebih sering berkumpul dengan sesama mahasiswa Thailand daripada mahasiswa lokal dari Indonesia. Selain itu, mereka juga mengalami kendala dalam berkomunikasi walaupun sudah mendapatkan pelatihan intensif dari kampus. Permasalahan penyesuaian diri di masa awal perkuliahan pada mahasiswa asing Thailand di Unissula memang menjadi masalah yang harus diteliti. Selain mereka mengalami kesulitan dalam penyesuaian diri dengan lingkungan sekitarnya, cara berkomunikasi, kehidupan sehari-hari serta pertemanan, mereka juga mengalami kesulitan pada saat proses perkuliahan sehingga berdampak pada kondisi psikologis mahasiswa.

Budaya Thailand tentu memiliki perbedaan dengan budaya yang ada di Indonesia khususnya Semarang yang masih menjunjung nilai-nilai kebudayaan Jawa. Hal tersebut menyebabkan mahasiswa asing menghadapi benturan dua budaya dalam kehidupan mereka. Dua budaya yang berbeda yang bersatu padu menghasilkan suatu budaya baru tanpa menghilangkan unsur-unsur asli dalam budaya tersebut disebut dengan akulturasi. Akulturasi merupakan proses sosial yang timbul apabila suatu kelompok manusia dengan suatu kebudayaan tertentu dihadapkan dengan unsur-unsur kebudayaan dari suatu kebudayaan asing yang sedemikian rupa, sehingga unsur-unsur kebudayaan asing itu lambat laun diterima dan diolah ke dalam kebudayaan sendiri tanpa menyebabkan hilangnya kepribadian kebudayaan sendiri (Koentjaraningrat, 1990). Menurut Berry, konsep akulturasi ditekankan berdasarkan dua sudut pandang yaitu sudut pandang akulturasi budaya dan sudut pandang akulturasi psikologis. Akulturasi budaya merujuk pada perilaku individu yang berinteraksi dengan budaya tertentu, sementara akulturasi psikologis menunjuk pada dinamika interpersonal dalam diri yang menghasilkan berbagai reaksi berbeda antara yang satu dengan yang lain, meskipun mereka dalam wilayah akulturasi yang sama.

Akulturasi psikologis (Psychology Acculturation) pertama kali dikemukakan oleh Graves yang didefiniskan sebagai proses adaptasi individu terhadap budaya baru. Lebih lanjut, Graves mengatakan bahwa akulturasi psikologis merupakan perubahan pada individu yang berpartisipasi dalam situasi kontak budaya non-dominan dimana individu menjadi anggotanya. Sedangkan Berry mengartikan akulturasi psikologis sebagai proses dimana individu mengalami perubahan, baik karena dipengaruhi oleh adanya kontak dengan budaya lain, serta karena berpartisipasi dalam perubahan akulturatif 
umum yang berlangsung dalam budaya mereka. Berdasarkan definisi yang dikemukakan oleh dua tokoh tersebut, maka bisa disimpulkan bahwa akulturasi psikologi (Psychology Acculturation) adalah proses adaptasi individu terhadap budaya baru yang menimbulkan perubahan secara psikologis dan memberikan dampak pada perilaku individu dalam upaya berpartisipasi sebagai kontak (hubungan) antar budaya. Kesimpulan ini mengungkapkan terjadinya sebuah akulturasi psikologis menunjukkan adanya proses adaptasi yang dapat diartikan bahwa dalam akulturasi psikologis individu mengalami penyesuaian diri (adjustment) dengan lingkungan sekitar.

Sebelum berimigrasi potensi akulturasi akan memudahkan individu untuk dapat beradaptasi. Adapun yang dikemukakan oleh Young Yun Kim terdapat beberapa faktor yang menentukan proses akulturasi tersebut, diantaranya (Deddy Mulyana, 2006):

1. Kemiripan

Terdapat adanya persamaan diantara kedua budaya, yakni budaya tempat individu melakukan imigrasi dengan budaya tempat tinggalnya. Kemiripan budaya ini dapat memudahkan individu dalam proses akulturasi.

2. Usia pada saat berimigrasi

Usia dan pendidikan terakhir individu ketika pertama kali berimigrasi juga berkaitan dengan proses akulturasi.

3. Latar belakang pendidikan

Pendidikan terakhir individu sebelum berimigrasi akan mempermudah proses akulturasi. Dalam hal ini merupakan pendidikan yang culture free atau bebas dari budaya tempat tinggalnya karena hal ini memberi dampak besar terhadap kapasitas seseorang untuk dapat mengatasi tantangan hidup dan pengalaman baru.

4. Kepribadian

Kepribadian yang senang berteman, tidak takut mengambil resiko, terbuka dalam berfikir dan memiliki toleransi merupakan faktor-faktor yang nantinya dapat membantu individu untuk menyesuaikan dengan lingkungan yang baru. Selain itu, karakteristik kepribadian ini dapat mengubah serta membentuk perilaku, perasaan dan persepsinya.

5. Pengetahuan

Memiliki insight mengenai budaya pribumi. Seperti telah melakukan perjalanan sebelumnya, belajar melalui media massa atau terdapat kontak-kontak antarpersona sehingga segala pengetahuan yang dimiliki individu sebelum berimigrasi akan memudahkan proses akulturasi imigran.

Tentu tiap individu memiliki potensi yang berbeda-beda untuk dapat melakukan akulturasi psikologis. Hal penting dari proses dasar akulturasi ialah komunikasi. Akulturasi dapat diidentifikasi dari pribumi yang memperoleh pola budaya melalui komunikasi begitupun dengan pendatang yang mendapatkan pola-pola budaya baru dari proses komunikasi masyarakat setempat. Dalam kasus mengenai migrasi, terdapat perbedaan bahasa antara bahasa asli individu dengan bahasa asli lingkungan barunya sehingga komunikasi ini memunculkan permasalahan lain yaitu terkait komunikasi non verbal seperti gerak mata, ekspresi wajah, jarak antar pribadi serta perbedaan mengenai pengaturan ruang serta pandangan mengenai penting atau tidaknya perilaku non verbal ini.

Adanya latar belakang yang berbeda dari tiap individu dalam hal komunikasi yang mana telah terekam secara baik dalam diri individu tentu akan sulit ketika individu dihadapkan oleh bahasa serta pola komunikasi yang baru sehingga individu akan merasa terasingkan dari lingkungan barunya. Maka 
hal inilah yang disebut dengan kejutan budaya (culture shock) (Fajar, 2009). Kejutan budaya dapat ditandai dengan keadaan stress dan ketegangan ketika menghadapi situasi yang tidak pernah ia temukan sebelumnya. Hal tersebut seperti gaya berpakaian, kondisi cuaca, perbedaan cara bahasa, perilaku antara pria dan wanita, makanan, relasi interpersonal, sistem pendidikan hingga kebiasaankebiasaan lain yang berbeda.

Sedih, cemas, jenuh, marah, sensitif hingga kehilangan rasa percaya diri ini merupakan tanda dan gejala psikologi yang mungkin akan timbul ketika individu mengalami culture shock. Alergi, maag, sakit kepala dan diare merupakan gejala psikosomatis yang timbul dari segi fisik. Munculnya gejala tersebut ini merupakan dampak dari individu yang mengalami kejutan budaya saat berpindah ke tempat baru yang berbeda dengan budaya aslinya. Dampak yang dirasakan oleh individu ini bisa berlangsung dalam waktu yang cukup lama yaitu bisa mencapai angka 5 tahun bagi individu yang sulit untuk dapat menyesuaikan dirinya dengan baik (Furnham, 1986). Maka dari itu, individu perlu memiliki strategi akulturasi yang baik untuk dapat menghadapi dampak yang muncul itu. Cara-cara individu atau kelompok dalam berhubungan dengan masyarakat dominan disebut dengan strategi akulturasi pikologis (John W. Berry, 1999). Terdapat empat macam strategi akuluturasi yang mengacu pada teori yang disusun oleh Berry, yaitu :

a. Intergrasi (integration)

Strategi ini menekankan pada pembagian dimana individu masih mempertahankan budaya asli tetapi tetap menerima budaya dari luar yang masuk. Individu yang mempertahankan nilai budaya asli juga mengadopsi nilai-nilai dari budaya luar sehingga perilaku individu akan terpengaruh oleh budaya tersebut.

b. Asimilasi (assimilation)

Individu menghilangkan budaya asli mereka dan lebih memilih menggunakan budaya baru. Jadi, dalam hal ini individu secara menyeluruh telah menganut nilai budaya luar.

c. Separasi (separation)

Dalam hal ini berkebalikan dari strategi asimilasi, yaitu yang dihilangkan adalah budaya luar yang masuk dimana individu menolak nilai budaya luar tersebut dan menggunakan nilai budaya asli yang telah mereka anut sebelumnya. Sehingga individu tidak membuat kontak dengan budaya luar.

d. Marginalisasi (marginalization)

Individu lebih memilih untuk tidak menggunakan budaya asli dan budaya luar, maka dalam hal ini akan sulit untuk melihat perubahan yang terjadi pada individu dengan datangnya budaya luar tersebut, disatu sisi individu juga menolak untuk mempertahankan nilai budaya asli mereka.

Berdasarkan permasalahan yang telah dipaparkan di atas, penelitian ini bertujuan untuk mengungkap faktor, hambatan, dampak serta strategi akulturasi psikologis pada Mahasiswa Thailand di Universitas Islam Sultan Agung Semarang.

\section{Metode Penelitian}

Penelitian ini menggunakan teknik purposive dan snowball sampling di empat mahasiswa Thailand berhasil direkrut sebagai partisipan yaitu A (20th), B (20th), S (21th) dan R (22th). Seluruh penelitian berjenis kelamin laki-laki. Partisipan dipilih berdasarkan dua kriteria, yaitu berasal dari Thailand dan telah menempuh studi minimal 1 tahun di Universitas Islam Sultan Agung Semarang 
(Unissula). Empat mahasiswa tersebut menempuh studi di beberapa fakultas yaitu A dari Fakultas Bahasa dan Ilmu Komunikasi, B dari Fakultas Agama Islam, R dari Fakultas Ekonomi dan S dari Fakultas Keguruan dan IImu Pendidikan. Observasi dan wawancara dilakukan di lingkungan kampus yaitu di asrama mahasiswa, ruang pertemuan perpustakaan pusat dan taman kampus. Wawancara direkam menggunakan laptop dan smartphone sedangkan observasi dilakukan sebelum mulai wawancara dan sepanjang wawancara berlangsung.

Data dianalisis dengan menggunakan interpretative phenomenological analysis (IPA). IPA bertujuan untuk mengungkap secara detail bagaimana partisipan menafsirkan dunia personal dan sosialnya. IPA memungkinkan peneliti untuk mendapatkan pengalaman subjektif serta pemaknaan partisipan dalam menyesuaikan diri. Proses analisis data menggunakan langkah-langkah yang dikemukakan oleh Smith \& Eatough (2007). Analisis dimulai dengan mencatat hasil wawancara dan membaca setiap transkrip berulang kali untuk memahami apa yang partisipan rasakan. Transkrip bacaan diberi anotasi dan diberi kode dalam bentuk catatan peneliti. Catatan akan dieksekusi hingga seluruh transkrip dibaca, dan kemudian menafsirkan ulang catatan tersebut hingga kata atau frasa konseptual diperoleh. Selain itu, kata atau frasa konseptual dikelompokkan menurut kesamaan maknanya dengan yang lain dan ditandai sebagai sub topik. Kemudian sesuai kesamaan cakupannya, semua sub topik yang telah ditentukan dikelompokkan kembali dan diberi label dengan topik yang lebih besar atau lebih unggul. Proses akhir dari analisis data ini adalah mendapatkan tabel subjek dengan kutipan dari wawancara. Berdasarkan tabel tema ini kemudian dibuat laporan penelitian. Penelitian ini menggunakan kriteria evaluasi dengan cara mendasarkan interpretasi peneliti pada contoh ekstrak wawancara yang dikutip.

Metode yang disebutkan pada paragraf sebelumnya adalah grounding in example, penulis memberikan contoh ekstraksi data yang digunakan kemudian mengembangkannya berdasarkan pemahaman peneliti (Elliot, 1999). Dengan mengekstrak kutipan wawancara, pembaca dapat menguji argumen atau persuasi peneliti dengan membandingkan dengan pemahaman mereka sendiri. Peneliti mengarsip semua data dari laporan mulai dari pedoman wawancara, rekaman audio, transkrip, proses pengkodingan, hingga tabel tema sebagai bukti yang bisa ditelusuri jejaknya oleh pihak ketiga. Hal ini merupakan salah satu cara untuk memastikan transparansi proses penelitian.

\section{Hasil Penelitian}

Penelitian ini berhasil mengidentifikasi empat tema utama, yaitu faktor akulturasi psikologis, hambatan akulturasi psikologis, dampak akulturasi psikologis serta strategi akulturasi psikologis.

\section{Tema : Faktor Akulturasi Psikologis}

Keempat partisipan merasakan budaya asli mereka dengan budaya Indonesia hampir sama baik itu dari makanan pokok, kondisi lingkungan dan kebiasaan masyarakat.
"Cuacanya nggak beda, sama-sama panas" (A)
"Budaya Indonesia dengan budaya Thailand mirip-mirip aja" (B)
"Orang Indonesia dan Thailand sama-sama makan nasi, cuma rasanya yang berbeda" (R)

Selain itu, faktor kemiripan dimana keempat partisipan memilki kesamaan umur tingkat yang sama ketika pertama kali pindah ke Indonesia. 
Malisa Falasifah, Siti Maya Cahyanti, dan Amara Difa Nurl Hasanah J.M.

"Pertama kali ke Indonesia pada saat usia 19 tahun" (A)

"Saat awal pindah ke Indonesia berusia 19 tahun" (B)

"Sebelum pindah ke Indonesia pendidikan terakhirnya SMA Madrasah" (R)

"Pendidikan terakhir saya sebelum ke Indonesia Madrasah" (S)

Faktor kepribadian mahasiswa Thailand yang suka berteman membantu proses akulturasi selama studi di Unissula.

"Saya orangnya suka berteman dan teman saya dari Indonesia banyak" ( $R)$

"Saya suka berteman dan teman saya di sini sudah banyak" (S)

Keempat partisipan telah memiliki pengetahuan tentang bahasa Indonesia sebelum pindah ke Indonesia karena Bahasa Melayu masih sering digunakan di Thailand bagian Patani, karena Bahasa Melayu dan Bahasa Indonesia memiliki kemiripan maka mereka lebih mudah untuk memahami Bahasa Indonesia karena ada beberapa kata atau istilah yang digunakan adalah sama.

"Kalau saya itu kan di Thailand itu juga sering dengar Bahasa Melayu tapi kalau kaya Indonesia itu jadi tidak agak susah" (B)

"Di rumah saya pakai Bahasa Melayu, saya tinggal di Patani" (S)

Semua partisipan menjelaskan bahwa mereka merasakan budaya Thailand dan Indonesia memiliki kemiripan. Selain itu, keempat partisipan berusia remaja pada saat awal pindah ke Indonesia. Kepribadian mereka yang suka berteman menjadikan mereka memiliki banyak teman dari Indonesia. Partisipan juga menceritakan di daerah asal mereka masih menggunakan Bahasa Melayu yang memiliki kemiripan dengan bahasa Indonesia. Kesimpulannya, semua partisipan memiliki faktor akulturasi psikologis yang memudahkan mereka dalam menjalani proses akulturasi psikologis selama masa studi di Indonesia.

\section{Tema : Hambatan Akulturasi Psikologis}

Walaupun di tema sebelumnya yaitu berkaitan dengan faktor akulturasi psikologis semua partisipan memiliki semua faktor yang membantu proses akulturasi, namun semua partisipan pada awal migrasi ke Indonesia masih mengalami hambatan utama berupa komunikasi menggunakan Bahasa Indonesia.

"Saya pernah mengalami kesusahan karena pada awal kuliah saya masih kurang paham Bahasa Indonesia" (A)

"Nah masalah seperti saya gak berani nanya ke mana mana. Maksudnya nanya gimana gimana gak berani bertanya" $(R)$

Keempat partisipan mengalami hambatan dalam komunikasi dengan mahasiswa lain karena merasa kesulitan memahami bahasa yang digunakan oleh mahasiswa lain. Hal ini kemungkinan terjadi 
karena lingkungan kampus yang berada di Semarang khususnya masih kental dengan adat Jawa sehingga selain Bahasa Indonesia, mahasiswa atau masyarakat pribumi memiliki kebiasaan berkomunikasi menggunakan logat Jawa atau bahkan Bahasa Jawa dalam kehidupan sehar-hari sehingga partisipan merasa kesulitan untuk berkomunikasi dengan orang lain. Walaupun partisipan mengaku mereka sekarang lebih memahami bahasa Indonesia dan hanya mengalami kesulitan dari segi bahasa hanya di awal perkuliahan, namun dari segi observasi pada saat wawancara bisa disimpulkan bahwa 1 dari 4 partisipan yaitu A masih mengalami kesulitan dalam memahami Bahasa Indonesia. Hal ini dikarenakan partisipan masih kelihatan bingung dan kurang mampu menjawab pertanyaan dengan baik selama proses wawancara.

\section{Tema : Dampak Akulturasi Psikologis}

Dengan adanya hambatan berupa komunikasi, partisipan mengalami dampak akulturasi baik secara fisik atau psikologis yang bisa disimpulkan sebagai kejutan budaya (culture shock).

"Karena masalah UTS dan bahasa saya sering stress dan sakit kepala bahkan pernah pingsan satu hari" (A)

"Saya pernah stress karena ada kuliah yang mata kuliahnyaa tidak paham. Ada juga perasaan sendirian ngga ada siapa ngomong" (B)

"Saya pernah merasa stress gak mau keluar kamar tidur dua puluh empat jam sampai sakit demam. Tapi itu jarang" (R)

"Saya pernah demam tapi tidak sering. Mulai masuk semester 4 ini saya sudah mulai bisa adaptasi" (S)

\section{Tema : Strategi Akulturasi Psikologis}

Strategi akulturasi psikologis digunakan oleh partisipan untuk berhubungan langsung dengan masyarakat dominan yang memiliki budaya berbeda. Di dalam penelitian ini, partisipan menggunakan strategi integrasi yaitu tetap mempertahankan budaya asli mereka tetapi juga ingin berpartisipasi terhadap budaya luar yang masuk ke dalam budaya mereka. Strategi ini tertuang dalam kutipan wawancara dari dua partisipan berikut:

"Kalau sama teman Thailand pakai Bahasa Thailand. Kalau sama Indonesia pakai Bahasa Indonesia. Bisa menyesuaikan waktu" (S)

"Kalau sama teman Thailand itu pakai Bahasa Thailand. Kalau sama teman Indonesia pakai Bahasa Indonesia terus. Kalau kegiatan sehari-hari masih sama seperti yang dulu" (B)

Berdasarkan kutipan di atas partisipan sudah mampu untuk berbicara dalam dua bahasa yaitu Bahasa Indonesia dan Bahasa Thailand. Cara ini termasuk dalam strategi integrasi.

\section{Pembahasan}

Hasil penelitian menunjukan bahwa keempat partisipan tidak terlalu kesulitan dalam menjalani proses adaptasi di Indonesia. Hal ini dibuktikan dengan pernyataan yang mereka berikan 
Malisa Falasifah, Siti Maya Cahyanti, dan Amara Difa Nurl Hasanah J.M.

bahwa budaya yang ada di Indonesia dan Thailand hampir sama, hal ini mungkin dapat terjadi karena partisipan berkuliah di lingkungan Islami. Partisipan kerap mengatakan bahwa pendidikan terakhir mereka ialah madrasah, yaitu istilah sekolah bagi pelajar Thailand yang muslim. Oleh karena itu, partisipan kurang merasa kesulitan dalam adaptasi budaya karena berdasarkan pernyataan salah satu partisipan ia mengatakan bahwa tempat dimana ia tinggal sekarang (Pesantren Unissula) sama dengan yang ada di Thailand. Mungkin hal tersebut yang memudahkan mereka untuk menerima lingkungan baru karena kegiatan yang dilakukan sehari-hari sama seperti yang biasa mereka lakukan.

Selain lingkungan sekitar yang mendukung sebagaimana telah dijelaskan di paragraf di atas, kemampuan interpersonal mereka yang suka berteman juga menjadi faktor pendukung untuk bisa beradaptasi. Menurut Rakhmat (2008) komunikasi interpersonal berpengaruh terhadap perilaku manusia yang saling berkaitan untuk membantu pertumbuhan manusia (Zain, 2020). Pernyataan ini memiliki arti bahwa ketika individu memiliki komunikasi interpersonal yang baik maka hal itu akan mempengaruhi perilaku dalam beradaptasi. Komunikasi interpersonal ini ditunjukan partisipan ketika mengalami kesulitan dalam perkuliahan maka mereka akan bertanya kepada teman sekelas. Namun komunikasi interpersonal ini tidak dapat dibangun begitu saja, keempat partisipan mengatakan bahwa bahasa merupakan hambatan yang paling mereka rasakan. Berdasarkan pernyataan dari partisipan $\mathrm{R}$ ia diawal sulit untuk bisa berinteraksi dan bersosialisasi dikarenakan keterbatasan bahasanya sehingga ia mengalami perasaan seperti selalu sendirian dan tidak punya teman serta tidak berani untuk bertanya terlebih dahulu. Namun hal tersebut dapat diatasi dan ia mengatakan bahwa sekarang sudah lebih baik, biarpun masih sedikit mengalami kesulitan tetapi sudah tidak seperti pertama kali.

Berasal dari negara yang jauh, tentu individu akan mengalami culture shock dan dukungan sosial sesama mahasiswa Thailand ini akan memiliki banyak pengaruh dalam proses adaptasi. Hal ini sesuai dengan penelitian yang menyatakan bahwa faktor penting dalam menghadapi culture shock ialah adanya dukungan sosial (Herawati, 2020). Dukungan sosial dapat berupa banyak hal, seperti saling memberi semangat atau mengikuti organisasi. Berdasarkan wawancara yang dilakukan dengan partisipan S, ia menyatakan bahwa terdapat organisasi Thailand, yang mana organisasi tersebut merupakan perkumpulan mahasiswa Thailand di Unissula. Kegiatan yang mereka lakukan ialah pada setiap malam jum'at mereka ngaji yasin bersama-sama serta dalam kesempatan lain mereka juga mengadakan bakti sosial ke panti asuhan. Apa yang mereka lakukan ini sebagai bagian dari proses saling memberi dukungan serta melatih kemampuan interpersonal dalam berinteraksi dengan warga luar. Berdasarkan pernyataan yang diberikan partisipan $\mathrm{R}$, ia mengatakan bahwa mereka juga memiliki acara dengan mahasiswa Thailand lain yang ada di Semarang, seperti Unimus dan Unnes. Luasnya jaringan pertemanan sesama mahasiswa Thailand inilah yang akan membangun dukungan satu dengan lainnya. Hal ini sesuai dengan pernyataan bahwa dukungan sosial sangat dibutuhkan oleh mahasiswa internasional karena mereka sering merasa kesepian akibat jauh dari keluarga (Herawati, 2020), maka dari itu memiliki sesama teman dari Negara yang sama akan sangat membantu.

Di sisi lain dari perjuangan mereka dalam beradaptasi dengan budaya baru, keempat partisipan mengatakan bahwa mereka pernah merasa stress, seperti sakit perut, demam, sakit kepala hingga pingsan. Namun apa yang mereka rasakan tidak berlangsung lama dan sangat jarang mereka rasakan. Berdasarkan pernyataan partisipan A perasaan stress yang ia alami tidak sampai membuat mereka ingin pulang kerumah dikarenakan mereka memiliki teman disini dan mendapat dukungan semangat dari teman sekamarnya. Pernyataan partisipan sesuai dengan pendapat yang dikemukakan Fatimah (2010) yakni individu yang dapat menyesuaikan diri dengan baik maka ia tidak akan 
menunjukan gejala ketegangan emosional yang berlebih (Kustanti, 2018). Selain dampak negatif yang mereka rasakan, salah satu partisipan juga menyatakan bahwa ia merasa senang berkuliah di Indonesia karena ia dapat memiliki banyak pengalaman baru seperti dapat berpergian keluar kota dan mendaki gunung.

\section{Kesimpulan}

Berdasarkan pembahasan hasil penelitian ini maka dapat disimpulkan bahwa mahasiswa asing yang berasal dari Thailand di Universitas Islam Sultan Agung (Unissula) Semarang mengalami hambatan dalam proses akulturasi psikologis berupa hambatan komunikasi. Walaupun seluruh partisipan dalam penelitian ini memiliki sebagian besar faktor potensi proses akulturasi psikologis, namun hal tersebut belum mampu menangani hambatan yang timbul. Hambatan utama yang dihadapi seluruh partisipan adalah komunikasi karena adanya perbedaan bahasa. Hambatan tersebut memunculkan dampak akulturasi berupa kejutan budaya (cultural shock). Namun, adanya hambatan dan dampak yang mereka alami membuat mereka melakukan strategi akulturasi psikologi. Strategi yang digunakan oleh partisipan dalam penilitian ini adalah strategi integrasi dimana partisipan masih mempertahankan budaya dan bahasa Thailand namun pada waktu yang sama mereka berusaha untuk beradaptasi dengan budaya dan Bahasa Indonesia. Secara umum, meskipun para partisipan menghadapi berbagai kesulitan dalam berhubungan sosial dengan mahasiswa dan masyarakat lokal karena adanya perbedaan bahasa, namun hal ini biasanya terjadi di awal masa studi.

\section{Daftar Pustaka}

Deddy Mulyana, J. R. (2006). In Komunikasi Antarbudaya:Panduan Berkomunikasi dengan OrangOrang Berbeda Budaya (p. 146). Bandung: Remaja.

Elliot, R. F. (1999). Envolving Guidelines For Publication of Qualitative Research Studies In Psychology And Related Fields. British Journal of Clinical Psychology, 38, , 215-229.

Fajar, M. (2009). In Ilmu Komunikasi: Teori dan Praktik (p. 306). Yogyakarta: Graha Ilmu.

Furnham, A. \&. (1986). Culture shock, psychological reaction to unfamiliar environment. New York: Cambrige.

Herawati, I. R. (2020). Gegar Budaya Ditinjau dari Dukungan Sosial. Journal An-Nafs: Kajian Penelitian Psikologi Vol. 5 No. 1 Juni 2020, 96.

John W. Berry, Y. H. (1999). In Psikologi Lintas Budaya: Riset dann Aplikasi (p. 541). Jakarta: PT Gramedia.

Koentjaraningrat. (1990). Sejarah Teori Antropologi II. Jakarta: Universitas Indonesia Press.

Kustanti, A. O. (2018). Hubingan Antar Gegar Budaya Dengan Penyesuaian Diri Pada Mahasiswa Bersuku Minang di Universitas Diponegoro. Jurnal Empati, April 2018, Volume 7 (Nomor 2), halaman 48-65, 50. 
Malisa Falasifah, Siti Maya Cahyanti, dan Amara Difa Nurl Hasanah J.M.

Zain, M. R. (2020). Penyesuaian Diri dan Komunikasi Interpersonal Pada Mahasisawa Asing Yang Mengalami Gegar Budaya di Institut Agama Islam Negeri (IAIN) Kota Samarinda. Psikoborneo, Volume 8, Nomor 1, 2020 : 163-176, 173. 